\title{
News sections, journalists and information sources in the journalistic coverage of crises and emergencies in Spain
}

\author{
Marcos Mayo-Cubero
}

Nota: Este artículo se puede leer en español en:

http://www.elprofesionaldelainformacion.com/contenidos/2020/mar/mayo_es.pdf

How to cite this article:

Mayo-Cubero, Marcos (2020). "News sections, journalists and information sources in the journalistic coverage of crises and emergencies in Spain”. El profesional de la información, v. 29, n. 2, e290211.

https://doi.org/10.3145/epi.2020.mar.11

Manuscript received on $21^{\text {st }}$ March 2019 Accepted on $16^{\text {th }}$ December 2019

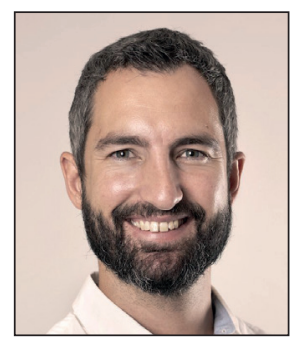

\author{
Marcos Mayo-Cubero \\ https://orcid.org/0000-0001-6306-3090 \\ Nebrija University \\ School of Communication and Arts \\ Campus Madrid-Princesa \\ Santa Cruz de Marcenado, 27 \\ 28015 Madrid, Spain \\ mmayo@nebrija.es
}

\begin{abstract}
Media social responsibility is rarely more evident than in the news coverage of a crisis, disaster or emergency. This research analyses the use of and trust in information sources through a nationwide survey of 30 editors-in-chief of Spain's most relevant newspapers, radio, television and online media outlets $(\mathrm{N}=30)$. With a very high response rate $(76.66 \%)$, the findings confirm that the use of unofficial sources (victims and those affected) are prioritized over official government sources. It is significant that the inferential analysis reveals that the editors give the same credibility as a source of information to the government as it does to the victims in the current context of misinformation, fake news and hoaxes. It is concluded that newsmaking should be built on the balanced use of official and unofficial sources. The results also confirm that the entire newsroom participates in this coverage and no journalistic specialization is detected amongst reporters.
\end{abstract}

\section{Keywords}

Risk communication; Catastrophes; Journalism; Disinformation; Fake news; Hoaxes; News; Editorial staff; Social media; Resilience; Information sources; Public organization; Political communication; Health communication; Public health crisis.

\section{Introduction}

\subsection{Social responsibility in crises}

The informational relevance of crises, disasters and emergencies is unquestionable. Google Trends has published the trends with the most searched terms in 2018 in the news category:

https://trends.google.es/trends/yis/2018/GLOBAL

Internationally, two hurricanes have been placed among the top ten most searched news items by a global audience: 'Hurricane Florence' in second place and 'Hurricane Michael' in sixth. Only the 2018 World Cup in Russia has exceeded the news interest in searches.

Acknowledgements

I thank the anonymous reviewers for their thoughtful and helpful suggestions for improving this article. 
In addition to natural and technological disasters, risk communication covers humanitarian, health and food crises, etc. This discipline is defined as the research discipline that studies the actors, communication processes, messages and effects on the audience in the contexts of crises, disasters and emergencies, regardless of the nature of their cause (Slovic; Weber, 2002). We are immersed in the so-called Risk Society, in which scientific and technological progress has exponentially multiplied risks with respect to previous times (Beck, 2002, p. 42). Most of these events generate occasional media interest linked to the moment of greatest impact of the emergency and forgetting the chronic triggering phase (Ardèvol-Abreu, 2015, p. 44). A discipline that currently takes on special relevance when examining an individual's perceived understanding of risk (Wrench, 2007, p. 64). In this context, the media expresses its social responsibility in making decisions about which news to offer, with what approach and with which information sources to use. In chaotic crisis scenarios, communication, in its broadest sense, must contribute through its informative messages to save lives and mitigate damage (Mayo-Cubero; Lavín; Gallardo-Camacho, 2017). From the theoretical perspective of framing, journalism has an outstanding role: it must adequately frame the crisis in order to collaborate in its solution and restore confidence under political leadership (Andrew et al., 2018, p. 249). In crises, the journalist should apply an informative logic that avoids the spectacularization, sensationalism and emotional hyperactivation of the audience (Souza-Mayerholz; Martínez-Ravanal, 2011, p. 75). As for the informative narrative, the theoretical review allows us to detect common features synthesized in the idea of the primacy of the spectacular over the informative (Hight; Smyth, 2003; Camps, 1999; Coté; Simpson, 2000). The media avoid rigour and focus on facilitating audience access to experiencing the instability generated by the disaster (Lozano-Ascencio, 2009). For example, the abuse in the audiovisual narrative of image sequences of destruction, suffering and looting is repeated (Pellegrini; Puente; Grassau, 2015, p. 262).

In crises, the journalistic story should be able to provide information that saves lives and minimizes damage in the short term. In the medium and long term, it should help the community to recover from tragedy and improve resilience to future disasters

\subsection{Official and unofficial sources}

After studying the Bhopal and Chernobyl disasters, Wilkins and Patterson concluded that the pattern of journalistic reporting on crises, emergencies and disasters is based on belief systems and social and cultural ideologies (Wilkins; Patterson, 1987). In their analysis, they argue that news coverage of crises is extremely complex for journalists, since they must explain to the public a phenomenon that often has multiple and invisible causes (Wilkins; Patterson, 1987, p. 80). In the informative narrative the sources constitute an essential component as conditioners of the content (agenda) and the approach (framing) (Van-Der-Meer et al., 2017). In this field of research, one of the most used typologies is the one established by Casero-Ripollés and López-Rabadán (2012, p. 16):

- official (governmental)

- political (parties)

- civil society (citizens, unions, associations, NGOs)

- media

- economic (companies)

- alternative (experts).

This research article adapts the typology of the authors to the context of crisis communication and continues the line established by Peter M. Sandman by distinguishing between official and unofficial sources:

- We understand official sources as information sources from the three levels of government (national, regional and municipal), in addition to information sources from the State security forces and corps, as well as the institutions involved in emergency management (Civil Protection, Police, Civil Guard, Fire Department, Military Emergency Unit and the Red Cross).

- In contrast, non-official sources are the victims and those affected by the crisis, disaster or emergency.

Pioneer in the study of information sources in Risk Communication, Peter Sandman, confirmed the excessive dependence of the media on official sources (Sandman, 1997, p. 257). Traditionally, research in the field of crises has focused on the reputation of private organizations. As a result, there is limited knowledge from the perspective of public organisations the main origin of official sources (Olsson, 2014). Some studies suggest that official sources should consider alliances with non-official sources in communication planning during the crisis (Vihalemm; Kiisel; Harro-Loit, 2012, p. 19).

In the Hispanic-American context, several investigations have confirmed the abuse of official sources through the analysis of the coverage of the Prestige oil tanker disaster off the Galician coast (Odriozola-Chéné, 2011) and the health crisis caused by horse meat (Marín-Murillo; Armentia-Vizuete; Caminos-Marcet, 2015, p. 42). Also, from the specific study of the television newscasts (Espinar-Ruiz; Samuelsson, 2012, p. 716). In contrast, other studies have determined the pre-eminence of non-official sources (victims and affected persons) in the informative narration (Oyanedel; Alarcón, 2010). 


\subsection{Trust in sources}

The trust attributed to the informative source in a crisis is a nuclear issue. Previous studies have gathered evidence that public motivation to react to an emergency is influenced by two factors: trust in the source that delivers the message and having experienced a similar dangerous situation (Fitzpatrick-Lewis et al., 2010, p. 13). In communication aimed at reducing risk, information especially regarding self-protection messages, must always comply with two premises: it must be reliable and up-to-date. A safe corridor to a shelter from the threat of fire will have limited temporal validity. Sometimes the sources considered most reliable by the public are not those that offer the most accurate and up-to-date information (Velez; Díaz; Wall, 2017, p. 469). It has been shown that there is a positive correlation between the amount of information and the credibility of the source (Peters; Covello; McCallum, 1997). This study determined that trust in the source depends on three factors:

- perception of expert knowledge;

- perception of transparency and honesty; and

- perception of concern and care (1997, p. 43).

In recent years, the implementation of ICTs and the expansion of social media have brought about intense changes in the context of emergency communication by reopening old debates about post-truth, fake news, credibility and, above all, media confidence in their news sources (Gualda; Rúas, 2019, p. 179). It has been found that in food crises, social media tend to amplify panic and hysteria in the public due to its reticular nature (Rutsaert et al., 2013, p. 88). However, other studies show that social media can help to strengthen citizens' trust in the messages coming from local politicians (official municipal sources) thanks to the perception of shared responsibility (Appleby-Arnold et al., 2019, p. 1). The integration of social media enables multi-directional dissemination of information from official and unofficial sources increasing community resilience and the responsiveness of the actors involved (Buzzelli et al., 2014, p. 441). To set up the messages from official sources, age is a first-order predictor variable. In a natural disaster, individuals aged 18-34 use social media (Twitter or Facebook, for example) as the first source of information ahead of television and radio (Park; Avery, 2018, p. 75). Recent research has shown that the receiver will react more quickly if the information comes from a transmitter in the inner circle of trust and has a direct and/or online relationship than if it comes from television or radio (Brynielsson et al., 2018, p. 35). In a specific analysis about the purpose of information from social media, it has been found that journalists use this type of information mainly to verify data and obtain contacts (Mayo-Cubero, 2019, p. 43). Also, to search for material and to get documented (Canavilhas; Ivars-Nicolás, 2012, p. 63).

In the Spanish context, it has been detected that the atomization and fragmentation of the informative story in the media causes journalists to mistrust the use of social networks as a source of information (Varona-Aramburu; Sánchez-Muñoz, 2016, p. 801). In this sense, various authors show the need to continue providing evidence and meta-analysis in the still little explored field of social media in Risk Communication (Toppenberg-Pejcic et al., 2019, p. 7; Eriksson; Olsson, 2016, p. 10).

\subsection{Discredit of the official sources in Spain}

In the news scenario of a crisis, the needs of journalists and politicians often conflict (Rodríguez; Odriozola-Farré, 2012, p. 588). Faced with the conflicting interests of the different news sources involved, the journalist must maintain his or her balance and gather only contrasting information to avoid becoming a spokesperson for official and/or unofficial sources (Toledano; Ardèvol-Abreu, 2013, p. 210). Cases of concealment or manipulation of information by politicians in crisis situations have been documented (Ratzan; Moritsugu, 2014, p. 1213; Cho; Hong, 2016, p. 221). In the Spanish context, several studies have made visible the deep discredit of the official sources, mainly of political character, in the communicative management of the analyzed crises (Lozano-Ascencio, 2009; Elías, 2006; González-Villariny, 2008; Ibáñez-Peiró, 2014). It can be deduced that one of the factors that has had a notable influence on the serious decline in the loss of credibility of political institutions in Spain has related to the scant attention paid to ethical and deontological standards. On occasion, Spanish public administration has prioritised the protection of its own image over citizens' right to information by means of practices such as data concealment, information manipulation and/or the use of crises for political purposes (Mayo-Cubero, 2017, p. 234).

\subsection{Research objectives and hypotheses}

The construction of the theoretical framework has allowed us to see that most previous research approaches the phenomenon from a quantitative perspective using content analysis as a technique. It has been pointed out that this technique cannot capture the full complexity of the discourse and that part of the information is lost in the codification process (Keyton, 2019, p. 230). In this sense, different researchers agree on the need to overcome this approach and bet on analyses that complement and enrich the vision of the phenomenon with new approaches (Rutsaert et al., 2013, p. 88; Vélez; Díaz; Wall, 2017, p. 475; Latré; Perko; Thijssen, 2018, p. 108). The objective of this research is to advance precisely along this path by collecting the opinions and perceptions of a sample of experts. The aim is to capture, describe and analyse data on the work of the newsroom, journalists and the use of official and non-official sources in the coverage of crises and emergencies in Spain. This research is guided by six research questions:

RQ1. What news sections are involved in covering crises, emergencies and disasters?

RQ2. How many journalists are dedicated to covering this news exclusively in the newsrooms? 
RQ3. How many journalists cover this type of news in the crises and emergencies that have occurred in Spain, although not exclusively?

RQ4. How many journalists cover this type of news in crises and emergencies occurring abroad, although not exclusively?

RQ5. How often do the media use official and unofficial sources in their coverage of crises, emergencies and disasters?

RQ6. What confidence does the media place in official and unofficial sources for this type of coverage?

The following research hypotheses are formulated below:

$\mathrm{H1}$ : There is a significant relationship between the frequency of use of official information sources (national, regional and municipal governments, Civil Protection and others) and non-official sources (victims and affected persons) in the coverage of crises, disasters and emergencies.

$\mathrm{H} 2$ : There is a significant relationship between trust in official information sources (national, regional and municipal governments, Civil Protection and others) and non-official sources (victims and affected persons) in the coverage of crises, disasters and emergencies.

\section{Material and methods}

\subsection{Basic unit of analysis}

The data comes from a survey of 30 editors-in-chief of the main media in Spain in four platforms: television, radio, press and online media. The population under analysis is made up of the most important news outlets in Spain. We start from the premise that they are all those that meet two criteria: one thematic (generalist) and another of scope (national). Since there was no previous real census to determine which were these media, the size of the population could not be established. One of the contributions of this research, to overcome this limitation, is the construction of a census that allows for the estimation of the population investigated $(\mathrm{N}=30)$.

The criteria followed for the sampling procedure are described below.

The census was taken from the most similar previous research on the Spanish information ecosystem: 14 media in three platforms (Soengas-Pérez; Rodríguez-Vázquez; Abuín-Vences, 2014, p. 110). To achieve greater representation of the population, it was decided to double the census in this study (2014, p. 110) and expand it to 30 media outlets. It was decided to include the platform of digital native media (online media), which had not been taked into account in the previous research (2014, p. 110) since a lack of empirical evidence had been detected during the construction of the theoretical framework (Table 1). Thus, the media that make up this study's census were selected according to the relevance of their audience by taking four sources of information:

- OJD (press)

- EGM (radio)

- Kantar Media (television)

- Comscore (online media).

The 7 newspapers with the highest circulation $(O J D)$, the 9 television stations with the highest audience (Kantar Media), the 4 radio stations with the highest audience ( $E G M)$ and the 10 online native media with the highest digital consumption (ComScore) were selected. In addition, a stratified quota system was established (Vinuesa-Tejero, 2005, p. 188; Sevillano-García; Bartolomé-Crespo; Pascual-Sevillano, 2007, p. 194) to guarantee the representativeness of the four platforms analyzed.

\subsection{Expert sample}

The justification for the research technique lies in the fact that the survey allows the opinion of a group to be captured to determine the intentionality of the majority opinion stream (Vinuesa-Tejero, 2005). Thus, it was decided that it would be appropriate to design a sample of experts who would gather the perspective of the specialists on the object of study (Hernández-Sampieri; Mendoza-Torres, 2018, p. 429).

One of the key strategic decisions was to target the news directors or editors-in-chief as key informants. It was considered that the editors, as the most responsible persons for the news content of each media, had the most authoritative opinion to answer the questionnaire. In other words, their answers reflect the guideline for the working routines of all journalists in the newsroom. We would like to point out that initially the possibility of directing the survey to journalists was considered, since it was considered that it would be more affordable to achieve a satisfactory response rate. In the end, the idea was rejected as the data collected would have been less reliable and valid. During the construction of the theoretical framework, surveys aimed at journalists were detected, but not at the editors-in-chief of the main media (Van-Der-Meer et al., 2017, p. 1107). For instance, the most complete radiography of the journalistic panorama in Spain, the annual report of the Madrid Press Association (APM), does not go into detail on the specific aspects related to crisis communication. This article aims to complement and enrich works such as those of the APM with the knowledge provided in terms of editorial work and news sections, journalistic specialization and information sources in crisis reporting contexts. 


\subsection{Data collection tool}

The design of the questionnaire was based on previous research on hurricane Katrina coverage (Duhé, 2008, p. 117). The bibliographic review allowed the design of a first draft that was evaluated by a panel of three experts in the field of research ${ }^{1}$.

A second draft, with significant improvements, was administered to a strategic group of ten journalists from the four media platforms. The validity and reliability of the collection tool was tested with this test. Finally, a questionnaire was developed with 32 closed questions, multiple choice and Likert scales. The questionnaire was applied to the sample of experts through the platform www.e-encuesta.com during three months (April 13 - June 13, 2015). The average completion time was 35 minutes and the response rate achieved was very satisfactory, finaIly reaching $76.66 \%(n=23)$. In other words, the three basic premises for this research technique were met: response rate, completion rate, and validity (Keyton, 2019, p. 154; Denscombe, 2017, p. 184).

\subsection{Data analysis}

Although the questionnaire explored several aspects and related topics, only the variables directly related to the research questions and the hypotheses formulated have been selected. A deductive criterion has been followed for the inclusion of the research results: news sections, journalists and information sources. In other words, firstly, it is explained how the newsroom is organised to deal with the news coverage. Then, what kind of journalists are involved and whether they are specialized or not. And thirdly, what information sources, official and non-official, are handled in terms of frequency of use and trust attributed.

The data analysis was carried out with the statistical analysis program SPSS, version 25. According to the level of measurement of the variables analyzed, the analysis strategy consisted of the extraction of the descriptive statistics, frequencies, percentages and standard deviations (SD). The measure of internal consistency was calculated with Cronbach's alpha coefficient. Several authors agree in qualifying the reliability of a coefficient of 0.7 as acceptable, 0.8 as positive and 0.9 as very positive (Garson, 2013; Tavakol; Dennick, 2011; Hutchinson, 2003). Subsequently, the variables were subjected to the Shapiro-Wilk normality test (Shapiro; Wilk, 1965). This test is suitable when the samples analyzed are less than 50 cases (Mohd-Razali; Bee-Wah, 2011, p. 25). The test confirmed that none of the variables had a normal distribution so an analysis of non-parametric bivariate correlations was chosen, calculating Spearman's rho coefficient for the hypothesis-contrast test. This coefficient was considered to be the most appropriate for the inferential analysis of the Likert type scales, considered as ordinals for statistical purposes (Hernández-Sampieri; Mendoza-Torres, 2018, p. 367).

\section{Findings}

\subsection{News sections in the coverage of crises and emergencies}

The question was formulated as follows:

'What news section(s) is/are usually involved in the coverage of news related to disasters, crises and emergencies? Point out all the options you consider' (Graph 1).

It was decided to use this formula to capture all the nuances in the responses. During the preparation of the questionnaire, it was detected how these coverages posed needs to the directors that involved the whole newsroom. The results 
show that in most of the large Spanish media, this coverage requires the work of the entire newsroom (65\%). In addition, the balanced weight of each section in this coverage is provided. In $57 \%$ of the media, the section that contributes more journalists is International, Society (52\%), National or Politics (39\%), Local (26\%) and Police reports (9\%).

\subsection{Journalists specialized in cove- ring crises and emergencies}

The findings show that most of the Spanish media do not have journalists dedicated exclusively to the coverage of this kind of news stories (74\%). Identical percentage $(4 \%)$ register the media that have a journalist, between 2 and 5, and more than 5 dedicated exclusively to this informative task (Graph 2).

The results show that the most common team that a media outlet sends out to cover a crisis or emergency is made up of between one and three journalists (for $30 \%$ of the media outlet if it is in Spain and for $39 \%$ if it is abroad). $17 \%$ of the media do not assign any journalist if the crisis is international (Graph 3).

\subsection{Information sources in crises and emergencies}

We observe in Table 2 that the information sources most used by the media are the Police, Civil Guard, Military Emergency Unit (UME) and Red Cross (91.3\%). The second most used are the non-official sources: victims and affected people $(78.3 \%)$ ahead of the official government sources.

On the third level are the government sources at the regional and municipal level $(73.9 \%)$. In fourth place, Civil Protection (69.6\%). In fifth position as an informative source, which is always resorted to, is the national government (65.2\%). The value registered by Cronbach's alpha coefficient for the six items analyzed reaches a positive value (0.83).

Table 2. Frequency of use of information sources in crisis $(n=23)$

\begin{tabular}{|c|c|c|c|c|c|}
\hline & \multirow{3}{*}{$\begin{array}{c}\text { Always (\%) } \\
65.2\end{array}$} & \multirow{3}{*}{$\begin{array}{c}\text { Usually (\%) } \\
34.8\end{array}$} & \multirow{3}{*}{ Rarely (\%) } & \multirow{3}{*}{$\begin{array}{c}\text { SD } \\
0.48\end{array}$} \\
\hline & & & & & \\
\hline \multirow{5}{*}{ Official sources } & National Government & & & & \\
\hline & Regional Government & 73.9 & 21.7 & 4.3 & 0.55 \\
\hline & Municipal Government & 73.9 & 21.7 & 4.3 & 0.55 \\
\hline & Civil Protection & 69.6 & 21.7 & 8.7 & 0.65 \\
\hline & Other: Police, Civil Guard, Fire Department, UME, and Red Cross & 91.3 & 8.7 & & 0.73 \\
\hline Unofficial sources & Victims and affected persons & 78.3 & 17.4 & 4.3 & 0.54 \\
\hline
\end{tabular}

Cronbach's alpha $=0.83$

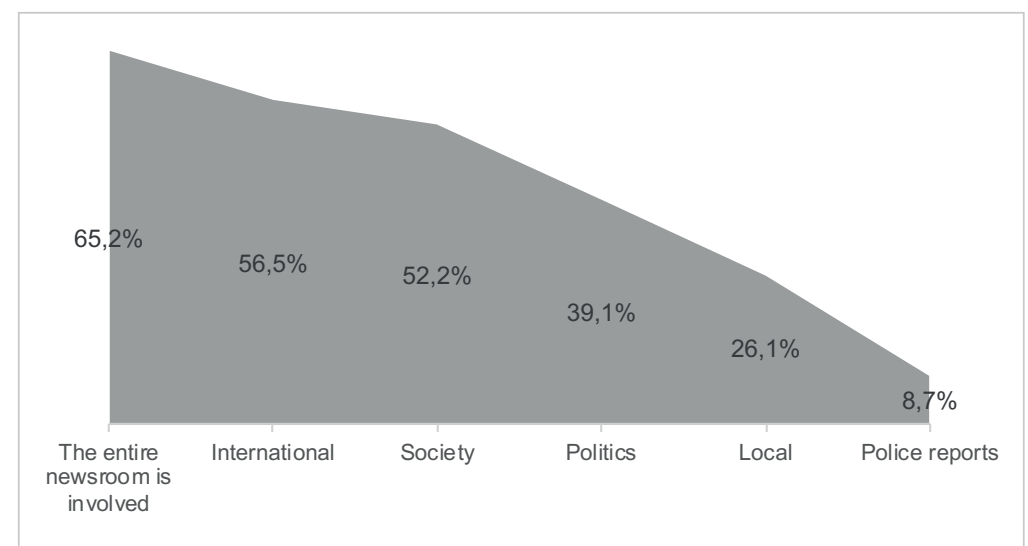

Graph 1. Percentage of media by section involved in coverage of crises and emergencies $(n=23)$

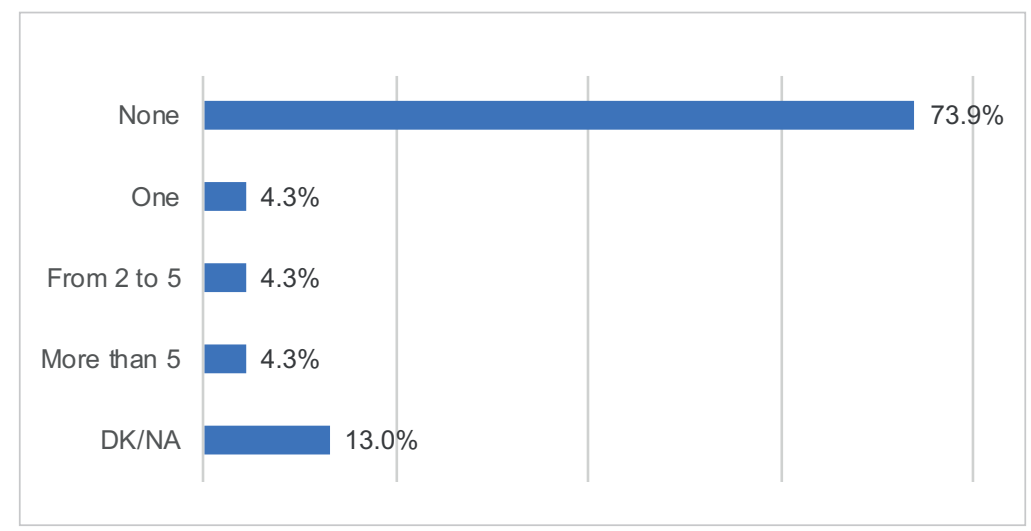

Graph 2. Percentage of media outlets by newsroom journalists covering exclusively crises and emergencies $(n=23)$

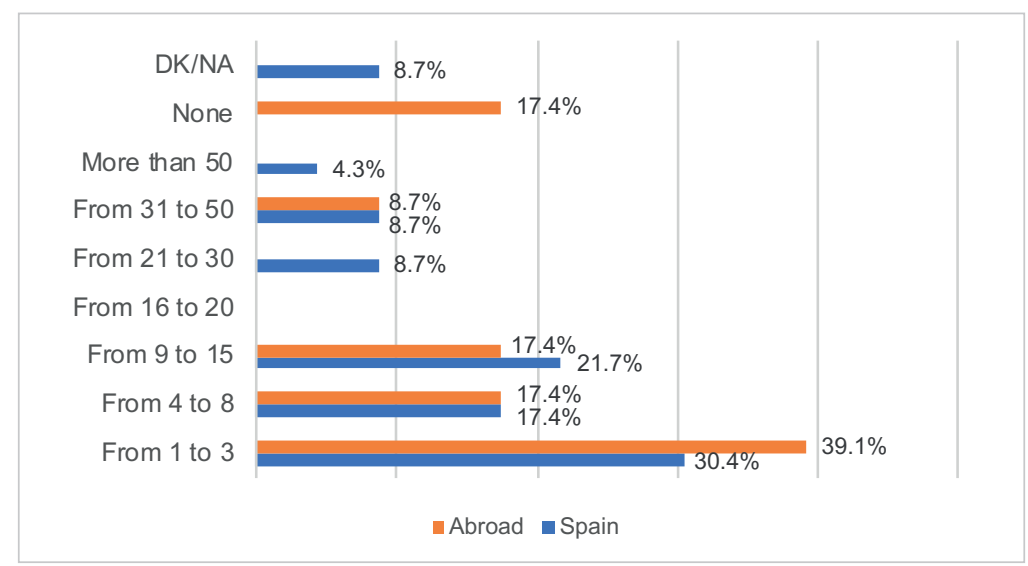

Graph 3. Percentage of media by journalists covering crisis news, but not exclusively $(n=23)$ 
The findings confirm (Table 3 ) that the most reliable information sources for the media are the Police, Civil Guard, UME and the Red Cross. Respondents say they have great confidence in the information provided by these sources (73.9\%). In second place is Civil Protection (60.9\%). In third place and with the same confidence rate are the official government sources (30.4\%), at the national and municipal levels, and the non-official sources, victims and affected persons (30.4\%). The regional government registers a slightly lower confidence (26.1\%). The value registered by the Cronbach's alpha coefficient for the six analyzed items reaches a positive value $(0.84)$.

Table 3. Confidence in sources of information in crisis $(n=23)$

\begin{tabular}{|c|c|c|c|c|c|}
\hline & & Always (\%) & Usually (\%) & Rarely (\%) & SD \\
\hline \multirow{5}{*}{ Official sources } & National Government & 30.4 & 60.9 & 8.7 & 0.60 \\
\hline & Regional Government & 26.1 & 60.9 & 13 & 0.62 \\
\hline & Municipal Government & 30.4 & 56.5 & 13 & 0.65 \\
\hline & Civil Protection & 60.9 & 34.8 & 4.3 & 0.59 \\
\hline & Other: Police, Civil Guard, Fire Department, UME, and Red Cross & 73.9 & 26.1 & & 0.44 \\
\hline Unofficial sources & Victims and affected persons & 30.4 & 60.9 & 8.7 & 0.60 \\
\hline
\end{tabular}

Cronbach's alpha $=0.84$

Inferential analysis allows us to reject the $\mathrm{H} 1$. There are no significant correlations between the pairs of variables analyzed (Table 4).

Table 4. H1 contrast test with Spearman's rho coefficient

\begin{tabular}{|l|c|c|}
\cline { 2 - 3 } \multicolumn{1}{c|}{} & \multicolumn{2}{c}{$\begin{array}{c}\text { Unofficial sources } \\
\text { Victims and affected persons }\end{array}$} \\
\hline Official sources & n spearman's rho & p \\
\hline National Government & 23 & 0.297 \\
\hline Regional Government & 23 & 0.169 \\
\hline Municipal Government & 23 & 0.174 \\
\hline Civil Protection & 23 & 0.174 \\
\hline Other: Police, Civil Guard, Fire Department, UME, and Red Cross & 23 & 0.095 \\
\hline
\end{tabular}

Inferential analysis allows to validate the H2 for certain pairs of variables (Table 5). Spearman's rho coefficient shows significant positive correlations of strong intensities for the variable pairs 'CNationalGov' (confidence in national government) and 'Cvictims' (rho=0.770, p=0.000); 'CRegionalGov' and 'Cvictims' (rho=0.666, p=0.001) and 'CMunicipalGov' and 'Cvictims' (rho=0.609, $\mathrm{p}=0.002$ ) at the 0.01 level.

Table 5. Contrast test of H2 with Spearman's rho coefficient

\begin{tabular}{|c|c|c|c|}
\hline \multirow[b]{2}{*}{ Official sources } & \multicolumn{3}{|c|}{$\begin{array}{c}\text { Unofficial sources } \\
\text { CVictims and affected persons }\end{array}$} \\
\hline & $\mathbf{n}$ & Spearmans' rho & p (level 0.01) \\
\hline CNational Government & 23 & 0.770 & $0.000 * *$ \\
\hline CRegional Government & 23 & 0.666 & $0.001 * *$ \\
\hline CMunicipal Government & 23 & 0.609 & $0.002 * *$ \\
\hline CCivil Protection & 23 & 0.154 & 0.482 \\
\hline COther: Police, Civil Guard, Fire Department, UME, and Red Cross & 23 & 0.216 & 0.323 \\
\hline
\end{tabular}

\section{Conclusions}

In most of the main Spanish media, the coverage of crises implies the participation of the entire newsroom (65\%). We deduce that precisely because due to the extreme nature of these events, their news coverage exceeds the resources of one or several sections. The departments that contribute the most journalists to the news coverage of the crises are, in this order: International, Society, Politics, Local and Police reports. The findings suggest a lack of journalistic specialization in this area since most of the large media do not have any journalists dedicated exclusively to this type of cove- 
rage $(74 \%)$. The most common team for this coverage is formed between one and three journalists if the crisis is national (30\%) or international (39\%). That is, Spanish media tend to send more journalists to cover crises and emergencies if they occur abroad.

The most used information sources are the Police, the Civil Guard, the Military Emergency Unit (UME), and the Red Cross. It is especially significant that the second most used source is the victims and those affected by the tragedy (78.3\%). In other words, the editors-in-chief believe that non-official sources should be utilized more than official government sources. These results contrast with those gathered in previous investigations in which the abuse of official sources and the occasional presence of non-official sources (victims and those affected) are highlighted in the news story (Odriozola-Chéné, 2011, p. 90; Marín-Murillo; Armentia-Vizuete; Caminos-Marcet, 2015, p. 42; Espinar-Ruiz; Samuelsson, 2012, p. 716). However, the findings of this research are consistent with those recorded by Oyanedel and Alarcón who maintain that unofficial sources are more widely used (49\%) than official sources (16\%).

In terms of confidence, the media consider the Police, Civil Guard, Military Emergency Unit (UME), and Red Cross to be the most reliable information sources. Next comes Civil Protection, the security corps par excellence in emergencies in Spain. It is significant and paradoxical that the editors-in-chief give the same confidence to non-official sources (victims and affected people) as to official government sources in a context of information threatened by phenomena such as misinformation and fake news. The emergency scenario is especially prone to the dissemination of data that is biased and distorted by the impact of social media. In this sense, we start from the premise that the cornerstone of news coverage in a disaster must be public service with the dissemination of news that flees from alarmism, sensationalism and hoaxes. We consider that the results achieved on the mistrust of official government sources are revealing and highlight a problem: the significant discredit of institutional public communication in the management of the recent crises in Spain, generated by practices such as concealment of information, manipulation and use of crises for political purposes (Mayo-Cubero, 2017, p. 234).

The contrast of the hypothesis test confirms that there is no significant correlation between the frequency of use of official and unofficial sources ( $\mathrm{H} 1)$, but between the confidence in official and unofficial sources $(\mathrm{H} 2)$. The findings reveal positive correlations of strong intensities between confidence in non-official sources (victims and affected) and official government sources (national, regional and municipal). In other words, the findings suggest that the greater the trust in non-official sources (victims and affected persons), the greater the trust in official government sources.

\section{Crisis and emergency scenarios are es- pecially prone to the dissemination of data that is biased and distorted by the impact of social media}

From a psychological perspective, victims and those affected by the impact of a disaster, crisis or emergency will, to a greater or lesser extent, be in a state of post-traumatic stress. They will have suffered personal and/or material damage. The information they provide as a source to journalists cannot escape from this reality. By acting as an unofficial source, the data will possibly be biased, distorted and subject to their experience as survivors of the disaster. If the media's social responsibility requires a truthful, accurate and well-balanced news story, it should not be based largely on unofficial sources.

In theory, it is the official sources that should provide rigorous, reliable and emotionally balanced information. We therefore conclude that crisis reporting should be able to provide information that saves lives and reduces harm in the short term. In the medium and long term, it should also help the community to recover from the tragedy and improve resilience to future crises. And that information story can only be built from a balance between rigor and human interest, between the equal use of official and unofficial sources. However, the results suggest a reality far removed from this social responsibility of the media. We deduce that, in many crises, the media construct a tabloid and sensationalist story in search of an emotionally hyper-activated audience. We agree that the informative story of the catastrophe is built from the suffering of the victims (Oyanedel; Alarcón, 2010, p. 120). One of the limitations of the study is related to the size of the sample. We consider that the strategic sample includes the population under investigation: the main news media in Spain $(N=30)$. Although limited $(n=23)$, we consider that the representativeness, reliability and validity of this survey is guaranteed by the high response rate achieved (76.66\%). Therefore, we are confident that this unprecedented and solid sample of experts, which has brought together the 30 editors-in-chief of the most relevant outlets in the Spanish information ecosystem, can serve as a basis for future research in this compelling field of investigation.

Media social responsibility requires a truthful, accurate and well-balanced news story that should not be based mainly on unofficial sources 


\section{Note}

1. At this point, it was decided to group the national security forces, the Military Emergency Unit (UME) and the Red Cross under the category of 'Others' because they had common features, there were no significant differences in the results and in order not to lengthen the questionnaire too much.

\section{References}

Andrew, Simon A.; Arlikatti, Sudha; Chatterjee, Vaswati; Ismayilov, Orkhan (2018). "Ebola crisis response in the USA: Communication management and SOPs". International journal of disaster risk reduction, v. 31, pp. 243-250.

https://doi.org/10.1016/j.ijdrr.2018.04.028

Appleby-Arnold, Sandra; Brockdorff, Noellie; Fallou, Laure; Bossu, Rémy (2019). "Truth, trust, and civic duty: Cultural factors in citizens' perceptions of mobile phone apps and social media in disasters". Journal of contingencies and crisis management, v. 27, n. 4, pp. 293-305.

https://doi.org/10.1111/1468-5973.12282

Ardèvol-Abreu, Alberto (2015). "Building the agenda and news frames about countries facing humanitarian crises: News values and selection of information sources". Communication \& society, v. 28, n. 1, pp. 43-62.

https://doi.org/10.15581/003.28.1.sp.43-62

Beck, Ulrich (2002). La sociedad del riesgo global. Madrid: Siglo XXI Editores. ISBN: 9788432312618

Brynielsson, Joel; Granåsen, Magdalena; Lindquist, Sinna; Narganes-Quijano, Maribel; Nilsson, Susanna; Trnka, Jiri (2018). "Informing crisis alerts using social media: Best practices and proof of concept". Journal of contingencies and crisis management, v. 26, n. 1, pp. 28-40.

https://doi.org/10.1111/1468-5973.12195

Buzzelli, Michelle M.; Morgan, Paula; Muschek, Alexander; Macgregor-Skinner, Gavin (2014). "Information and communication technology: Connecting the public and first responders during disasters". Journal of emergency management, v. 12, n. 6, pp. 441-447.

https://doi.org/10.5055/jem.2014.0207

Camps, Sibila (1999). Periodismo sobre catástrofes. Buenos Aires: Ediciones Paulinas. ISBN: 9789500912761

Canavilhas, João; Ivars-Nicolás, Begoña (2012). "Uso y credibilidad de fuentes periodísticas 2.0 en Portugal y España”. El profesional de la informacion, v. 21, n. 1, pp. 63-69.

https://doi.org/10.3145/epi.2012.ene.08

Casero-Ripollés, Andreu; López-Rabadán, Pablo (2012). "La evolución del uso de las fuentes informativas en el periodismo español". En: III Congreso internacional comunicació i risc, marzo 2012, Tarragona, pp. 1-22. ISBN: 9788461556786

Cho, SeungHo; Hong, Sook-Yeong (2016). “Journalists' evaluation of the South Korean government's crisis management in the Cheonan incident". Journal of contingencies and crisis management, v. 24, n. 4, pp. 221-229.

https://doi.org/10.1111/1468-5973.12117

Coté, William; Simpson, Roger (2000). Covering violence. A guide to ethical reporting about victims and trauma. New York: Columbia University Press. ISBN: 9780231133937

Denscombe, Martyn (2017). The good research guide: For small-scale social research projects. London: McGraw-Hill Education. ISBN: 9780335226863

Duhé, Sonya-Forte (2008). "Communicating Katrina: A resilient media". International journal of mass emergencies and disasters, v. 26, n. 2, pp. 112-127.

http://ijmed.org/articles/291/download

Elías, Carlos (2006). “Medio ambiente, manipulación política y control mediático del riesgo. Análisis del caso del hundimiento del petrolero Prestige". Ámbitos, v. 15, pp. 171-190.

https://bit.ly/2U6DV3T

Eriksson, Mats; Olsson, Eva-Karin (2016). "Facebook and Twitter in crisis communication: A comparative study of crisis communication professionals and citizens". Journal of contingencies and crisis management, v. 24, n. 4, pp. 198-208.

https://doi.org/10.1111/1468-5973.12116

Espinar-Ruiz, Eva; Samuelsson, Anna (2012). "Riesgos medioambientales en los espacios informativos: Análisis cualitativo de la televisión española". Estudios sobre el mensaje periodistico, v. 18, n. 2, pp. 703-719.

https://doi.org/10.5209/rev_ESMP.2012.v18.n2.41041

Fitzpatrick-Lewis, Donna; Yost, Jennifer; Ciliska, Donna; Krishnaratne, Shari (2010). "Communication about environmental health risks: A systematic review". Environmental health, v. 9, n. 1, pp. 1-15.

https://doi.org/10.1186/1476-069X-9-67 
Garson, G. David (2013). Scales and measures. Asheboro, NC: Statistical Associates Publishers. ISBN: 9781626380127

González-Villariny, Natalí (2008). La comunicación del riesgo en la prensa escrita. Un estudio del tratamiento informativo del naufragio del petrolero Prestige en los diarios El país y El mundo. Tesis doctoral. Universidad Complutense de Madrid. ISBN: 9788469200711

https://eprints.ucm.es/8157

Gualda, Estrella; Rúas, José (2019). “Conspiracy theories, credibility and trust in information”. Communication \& society, v. 32, n. 1, pp. 179-195.

https://doi.org/10.15581/003.32.1.179-195

Hernandez-Sampieri, Roberto; Mendoza-Torres, Christian-Paulina (2018). Metodología de la investigación: Las rutas cuantitativa, cualitativa y mixta. México: Mc Graw Hill Education. ISBN: 9781456260965

Hight, Joe; Smyth, Frank (2003). Tragedias \& periodistas. Guía para una cobertura más eficaz. New York: Dart Center for Journalism and Trauma.

https://dartcenter.org/sites/default/files/TragediasYPeriodistas.pdf

Hutchinson, T. Paul (2003). "Dichotomization and manipulation of numbers". Canadian journal of psychiatry, v. 48, n. 6, pp. 429-430.

https://doi.org/10.1177/070674370304800621

Ibáñez-Peiró, Ángel (2014). Comunicación, administraciones públicas y gestión de la crisis y emergencias. Tesis doctoral. Universidad Complutense de Madrid.

https://eprints.ucm.es/29450

Keyton, Joann (2019). Communication research: Asking questions, finding answers. New York: McGraw-Hill Education. ISBN: 9781260085044

Latré, Edwin; Perko, Tanja; Thijssen, Peter (2018). "Does it matter who communicates? The effect of source labels in nuclear pre-crisis communication in televised news". Journal of contingencies and crisis management, v. 26, n. 1 , pp. 99-112.

https://doi.org/10.1111/1468-5973.12153

Lozano-Ascencio, Carlos (2009). "Periodismo de catástrofes: La actualidad informativa como fuente de incertidumbres". In: Moreno-Castro, Carlos (ed.). Comunicar los riesgos. Ciencia y tecnología en la sociedad de la información, pp. 231248. Madrid: Biblioteca Nueva.

https://bit.ly/2SNwIJj

Marín-Murillo, Flora; Armentia-Vizuete, José-Ignacio; Caminos-Marcet, José-María (2015). “Global news, local coverage: How the Basque press framed the horsemeat crisis". Communication \& Society, v. 28, n. 3, pp. 29-50.

https://doi.org/10.15581/003.28.3.sp.29-50

Mayo-Cubero, Marcos (2017). La especialización periodística como herramienta estratégica en la comunicación de catástrofes. Tesis doctoral. Universidad Complutense de Madrid.

https://eprints.ucm.es/42138

Mayo-Cubero, Marcos (2019). "Uso de las redes sociales en la cobertura periodística de crisis, desastres y emergencias en España". Revista española de comunicación en salud, n. 1, pp. 43-54.

https://doi.org/10.20318/recs.2019.4428

Mayo-Cubero, Marcos; Lavín, Eva; Gallardo-Camacho, Jorge (2017). "La cobertura informativa del terremoto de Lorca en España: la responsabilidad social del periodista". Ámbitos, n. 35, pp. 1-17.

https://revistascientificas.us.es/index.php/Ambitos/article/view/9139

Mohd-Razali, Nornadiah; Bee-Wah, Yap (2011). "Power comparisons of Shapiro-Wilk, Kolmogorov-Smirnov, Lilliefors and Anderson-Darling tests". Journal of statistical modeling and analytics, v. 2, n. 1, pp. 21-33.

https://www.nrc.gov/docs/ML1714/ML17143A100.pdf

Odriozola-Chéné, Javier (2011). "La construcción informativa de la catástrofe del Prestige: el abuso de las fuentes institucionales". Anàlisi, n. 44, pp. 77-92.

https://www.raco.cat/index.php/Analisi/article/view/248763

Olsson, Eva-Karin (2014). "Crisis communication in public organisations: Dimensions of crisis communication revisited". Journal of contingencies and crisis management, v. 22, n. 2, pp. 113-125.

https://doi.org/10.1111/1468-5973.12047

Oyanedel, Regina; Alarcón, Claudia (2010). "Reflexiones y desafíos: Una mirada al tratamiento televisivo de la catástrofe". Cuadernos.info, n. 26, pp. 115-122.

https://doi.org/10.7764/cdi.26.16 
Park, Sejin; Avery, Elizabeth-Johnson (2018). "Effects of media channel, crisis type and demographics on audience intent to follow instructing information during crisis". Journal of contingencies and crisis management, v. 26, n. 1, pp. 69-78. https://doi.org/10.1111/1468-5973.12137

Pellegrini, Silvia; Puente, Soledad; Grassau, Daniela (2015). "La calidad periodística en caso de desastres naturales: cobertura televisiva de un terremoto en Chile”. Estudios sobre el mensaje periodístico, v. 21, pp. 249-267. https://doi.org/10.5209/rev_ESMP.2015.v21.50678

Peters, Richard; Covello, Vincent; McCallum, David (1997). "The determinants of trust and credibility in environmental risk communication: An empirical study". Risk analysis, v. 17, n. 1, pp. 43-54.

https://doi.org/10.1111/j.1539-6924.1997.tb00842.x

Ratzan, Scott C.; Moritsugu, Kenneth P. (2014). "Ebola crisis - Communication chaos we can avoid". Journal of health communication, v. 19, n. 11, pp. 1213-1215.

https://doi.org/10.1080/10810730.2014.977680

Rodríguez, Pepe; Odriozola-Farré, Begoña (2012). "Catástrofes y periodismo: el relato, los escenarios, las interacciones y las necesidades prácticas y psicológicas de todos los implicados". Estudios sobre el mensaje periodístico, v. 18, n. 2, pp. 577-594.

https://doi.org/10.5209/rev_ESMP.2012.v18.n2.41033

Rutsaert, Pieter; Regan, Áine; Pieniak, Zuzanna; McConnon, Áine; Moss, Adrian; Wall, Patrick; Verbeke, Wim (2013). "The use of social media in food risk and benefit communication". Trends in food science \& technology, v. 30, n. 1, pp. 84-91.

https://doi.org/10.1016/j.tifs.2012.10.006

Sandman, Peter M. (1997). “Mass media and environmental risk: seven principles”. What risk?, v. 5, pp. $275-284$. https://doi.org/10.1016/B978-0-08-052100-8.50022-1

Sevillano-García, María-Luisa; Bartolomé-Crespo, Donaciano; Pascual-Sevillano, María-Ángeles (2007). Investigar para innovar en la enseñanza. Madrid: Pearson Educación. ISBN: 9788479913694

Shapiro, Samuel S.; Wilk, Martin B. (1965). "An analysis of variance test for normality (complete samples)". Biometrika, v. 52, n. 3/4, pp. 591-611.

https://www.jstor.org/stable/2333709?seq=1

Slovic, Paul; Weber, Elke (2002). "Perception of risk posed by extreme events". In: Risk management strategies in an uncertain world. New York: Palisades, April 12-13.

https://bit.ly/2vhJ9Cs

Soengas-Pérez, Xosé; Rodríguez-Vázquez, Ana-Isabel; Abuín-Vences, Natalia (2014). "La situación profesional de los periodistas españoles: las repercusiones de la crisis en los medios". Revista latina de comunicación social, v. 69, pp. 104124.

https://doi.org/10.4185/RLCS-2014-1003

Souza-Mayerholz, María-Dolores; Martínez-Ravanal, Víctor (2011). "La intervención de la televisión en el terremoto chileno". Comunicar, v. 18, n. 36, pp. 69-76.

https://doi.org/10.3916/c36-2011-02-07

Tavakol, Mohsen; Dennick, Reg (2011). "Making sense of Cronbach's alpha”. International journal of medical education, v. 2, pp. 53-55.

https://doi.org/10.5116/ijme.4dfb.8dfd

Toledano, Samuel; Ardèvol-Abreu, Alberto (2013). "Role of the media in disaster and humanitarian crisis: proposal for a social function of journalism". Communication \& society, v. 26, n. 3, pp. 190-213.

https://revistas.unav.edu/index.php/communication-and-society/article/view/36072

Toppenberg-Pejcic, Deborah; Noyes, James; Allen, Tomas; Alexander, Nyka; Vanderford, Marsha; Gamhewage, Gaya (2019). "Emergency risk communication: Lessons learned from a rapid review of recent gray literature on Ebola, Zika, and Yellow Fever". Health communication, v. 34, n. 4, pp. 437-455.

https://doi.org/10.1080/10410236.2017.1405488

Van-Der-Meer, Toni G. L. A.; Verhoeven, Piet; Beentjes, Johannes W. J.; Vliegenthart, Rens (2017). “Disrupting gatekeeping practices: Journalists' source selection in times of crisis". Journalism, v. 18, n. 9, pp. 1107-1124.

https://doi.org/10.1177/1464884916648095

Varona-Aramburu, David; Sánchez-Muñoz, Gema (2016). “Las redes sociales como fuentes de información periodística: motivos para la desconfianza entre los periodistas españoles". El profesional de la información, v. 25, n. 5, pp. 795-802. https://doi.org/10.3145/epi.2016.sep.10 
Vélez, Anne-Lise K.; Díaz, John M.; Wall, Tamara U. (2017). "Public information seeking, place-based risk messaging and wildfire preparedness in Southern California". International journal of wildland fire, v. 26, n. 6, pp. 469-477.

https://doi.org/10.1071/wf16219

Vihalemm, Triin; Kiisel, Maien; Harro-Loit, Halliki (2012). "Citizens' response patterns to warning messages". Journal of contingencies and crisis management, v. 20, n. 1, pp. 13-25.

https://doi.org/10.1111/j.1468-5973.2011.00655.x

Vinuesa-Tejero, María-Lourdes (2005). “La encuesta: Observación extensiva de la realidad social”. En: Berganza-Conde, María-Rosa; Ruiz-San-Román, José-Antonio (coords.). Investigar en comunicación: guía práctica de métodos y técnicas de investigación social en comunicación, pp. 177-205. ISBN: 8448198255

Wilkins, Lee; Patterson, Philip (1987). "Risk analysis and the construction of news". Journal of communication, v. 37, n. 3, pp. 80-92.

https://doi.org/10.1111/j.1460-2466.1987.tb00996.x

Wrench, Jason S. (2007). "The influence of perceived risk knowledge on risk communication". Communication research reports, v. 24, n. 1, pp. 63-70.

https://doi.org/10.1080/08824090601128182

\section{Colección de libros de bolsillo El profesional de la información (Editorial UOC) Últimos títulos publicados}
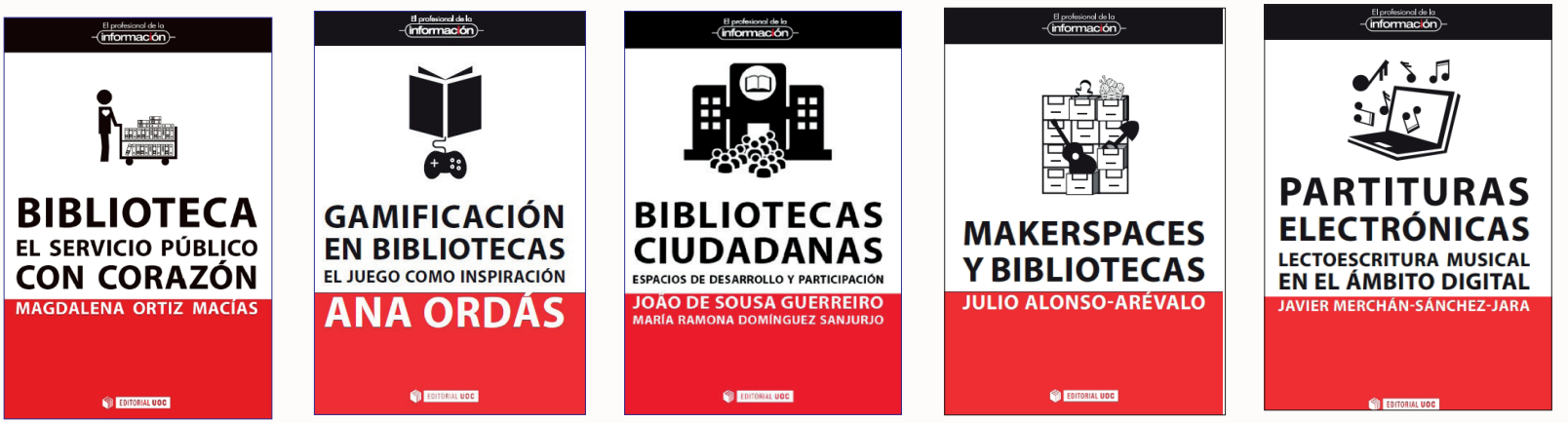

El profesional de la

\section{información}

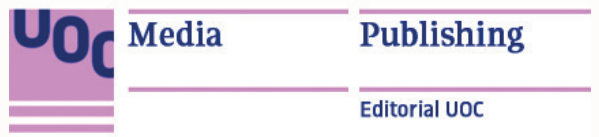

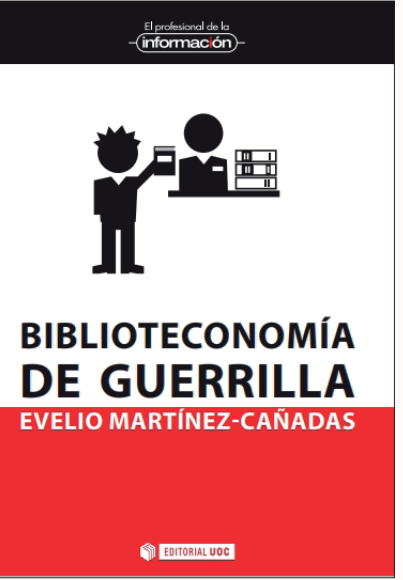

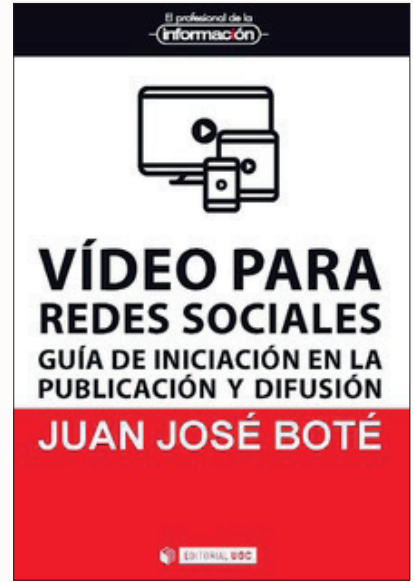

Más información:

http://www.elprofesionaldelainformacion.com/libros.html 